\title{
Nutritional aetiology of a neuropathy found in Tanganyika
}

\author{
By M. C. LATHAM \\ Nutrition Unit, Ministry of Health, Dar es Salaam, Tanganyika
}

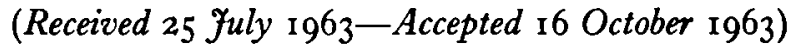

An ataxic neurological syndrome found in Tanganyika has recently been described by Haddock, Ebrahim \& Kapur (1962), who presumed this condition to be nutritional in origin. No accurate details were available of the diet consumed by the patients during the months before the onset of their disease, or of the diets of similar patients elsewhere in Africa (Money, 1958, 1959). In this paper, eight cases are described which had many clinical features similar to those described by Haddock and his colleagues. All these patients except one had been confined to prison for over 9 months, and three for over 18 months, before the onset of the illness. Their diet has been investigated, with results which seem to show that the syndrome has a nutritional origin. Public health measures that can be taken to prevent its occurrence are discussed.

\section{EXPERIMENTAL AND RESULTS}

Clinical features

Eight prisoners, adult male Tanganyika Africans, were admitted to the Princess Margaret Hospital in Dar es Salaam between July and September 1962. The work of all in prison was tailoring. All gave a history of pins and needles and severe burning pains in the feet. One patient described this sensation as being like 'sharp worms creeping about in the soles'. Some also said that they could not properly feel the ground with their bare feet (one described it as being like 'walking on soft rubber'). These symptoms became progressively worse and after a period varying from 2 to 12 weeks from their first onset the men began to have difficulty in walking. When admitted to hospital, four could not walk at all, and the other four had varying degrees of disability in this respect.

On examination, the patients showed no evidence of weight loss. All had some degree of motor weakness in the legs. Those that were able to walk tended to watch, rather carefully, where their feet were placed before taking each step, and, when standing, kept their feet well spaced. This behaviour was also seen in the other patients when they recovered sufficiently to walk. In six, the 'heel knee to ankle' test for ataxia showed a marked degree of loss of co-ordination. There was no evidence of optic atrophy or nerve deafness which was a frequent finding in the cases reported by Haddock et al. (1962). Objective sensory signs were not very marked. Six patients indicated that they had some loss of sense of light touch, but none entirely lacked sensation to a sharp pinprick. There was a diminution in deep pressure sense in four, 
and a loss of joint sense in five, of the patients. Ankle and knee jerks were diminished or absent in three.

The results of electrocardiograph, cerebrospinal fluid and serum protein examinations were normal in all. One gave a positive Kahn test. A full blood examination revealed some degree of anaemia in two, one of these having a severe anaemia with a haemoglobin concentration of $6.2 \mathrm{~g} / 100 \mathrm{ml}$. This patient had hookworm ova in the stools. Three had eosinophil counts above $15 \%$, but this is not an unusual finding in Tanganyika.

The patients were all treated with vitamin B complex, two tablets being given three times daily. Each tablet contained thiamine hydrochloride $5 \mathrm{mg}$, riboflavine $2 \mathrm{mg}$, nicotinamide $20 \mathrm{mg}$ and pyridoxine $2 \mathrm{mg}$. The patients received in hospital a daily diet consisting of maize $4 \mathrm{oz}$, rice $4 \mathrm{oz}$, bread $2 \mathrm{oz}$, beans $2 \mathrm{oz}$, red palm oil $\frac{1}{2} \mathrm{oz}$, meat $4 \mathrm{oz}$, mixed vegetables $4 \mathrm{oz}$, mixed fruit $4 \mathrm{oz}$, dried skim-milk powder $2 \mathrm{oz}$, sugar $\frac{1}{2} \mathrm{oz}$, salt $\frac{1}{\mathrm{o}} \mathrm{oz}$ and one medium-sized egg. Recovery was slow and variable.

Table I. Daily diet in Ukonga Prison, Tanganyika, before September 196r

\begin{tabular}{|c|c|c|c|c|c|c|}
\hline \multirow[b]{2}{*}{ Foodstuff } & \multicolumn{2}{|c|}{ Amount } & \multirow{2}{*}{$\begin{array}{l}\text { Thiamine } \\
\text { content } \\
\text { (mg) }\end{array}$} & \multirow{2}{*}{$\begin{array}{c}\text { Riboflavine } \\
\text { content } \\
\text { (mg) }\end{array}$} & \multirow{2}{*}{$\begin{array}{l}\text { Nicotinic } \\
\text { acid } \\
\text { content } \\
(\mathrm{mg})\end{array}$} & \multirow{2}{*}{$\begin{array}{c}\text { Calorie } \\
\text { content } \\
\text { (kcal) }\end{array}$} \\
\hline & $\mathbf{o z}$ & $\mathrm{g}$ & & & & \\
\hline $\begin{array}{l}\text { Maize meal, } 96 \% \text { extrac- } \\
\text { tion (Zea Mays L.) }\end{array}$ & 22 & $624 \cdot 6$ & $1 \cdot 87$ & 0.81 & $9 \cdot 37$ & 2261 \\
\hline $\begin{array}{l}\text { Beans, kidney } \\
\text { (Phaseolus vulgaris L.) }\end{array}$ & 4 & I 13.4 & 0.56 & 0.23 & $2 \cdot 27$ & 384 \\
\hline $\begin{array}{l}\text { Groundnuts, dry } \\
\text { (Arachis hypogaea L.) }\end{array}$ & 2 & $56 \cdot 7$ & 0.51 & 0.08 & $9 \cdot 64$ & 328 \\
\hline $\begin{array}{l}\text { Meat (beef) lean, whole } \\
\text { carcass }\end{array}$ & 1 & $28 \cdot 4$ & 0.03 & 0.06 & $\mathrm{I} \cdot 40$ & 56 \\
\hline Fruit, mixed, seasonal & 4 & 113.4 & 0.02 & 0.03 & 0.23 & $5 I$ \\
\hline $\begin{array}{l}\text { Vegetables, mixed, } \\
\text { seasonal }\end{array}$ & 4 & 113.4 & 0.09 & 0.10 & 0.56 & 51 \\
\hline $\begin{array}{l}\text { Red palm oil (Elaeis } \\
\text { guineensis Jacq.) }\end{array}$ & 0.5 & $14 \cdot 2$ & - & - & 一 & 127 \\
\hline $\begin{array}{l}\text { Milk, cow's, whole, } \\
\text { powder }\end{array}$ & 0.5 & 14.2 & 0.04 & 0.16 & 0.11 & 71 \\
\hline Salt & 0.5 & $14 \cdot 2$ & - & 一 & - & - \\
\hline Water & Ad lib. & - & - & - & - & 一 \\
\hline Total & - & - & $3 \cdot 12$ & $1 \cdot 47$ & $23 \cdot 58$ & 3329 \\
\hline
\end{tabular}

\section{Dietary investigation}

An investigation of the diet eaten by the prisoners was undertaken. The quantities of food issued, which are governed by law, had been unchanged for over 2 years, and are shown in the first column of Table $\mathrm{I}$. The food was all well stored and in good condition at the time of investigation. The preparation and serving of food were studied, and the prisoners were observed having routine meals. It was clear that all prisoners received helpings of similar size, but groundnuts were cooked separately, and some prisoners refused them.

White, highly milled maize meal was the staple food. It used to be unusual in institutions in Tanganyika, and had not previously been encountered by me in local prisons. 
A few months before the outbreak of the disease, the prison had switched from $96 \%$ extraction maize meal (locally known as dona) and had begun purchasing highly refined $60 \%$ extraction maize meal (locally known as sembe). This change in the type of maize purchased had not been accompanied by any other changes in the diet. It did not in the view of the prison authorities contravene the existing regulations (Laws of Tanganyika, 1956, Revised 1961: issued by authority First Parliamentary Draftsmen, Tanganyika; published by Government Printer; Cap. 58, p. 57) which state that $22 \mathrm{oz}$ of maize meal should be provided per prisoner per day, but which fail to mention the degree of refinement of the maize. The prisoners nearly all preferred the highly refined product.

The diet was assessed, accepted food tables (Platt, 1962) being used; the findings with regard to thiamine, riboflavine, nicotinic acid and calories are given in Table I. The results show that the diet supplies adequate quantities of these vitamins when a $96 \%$ extraction maize meal is used. However, a considerable reduction in the intake of these vitamins occurs when $60 \%$ extraction maize meal is used in the same quantities, with little difference in the calories supplied. Although these levels are rather lower than would normally be regarded as optimal levels of intake, they are not so low as to lead one to expect that nutritional disease would occur, even after prolonged intake.

Table 2. Daily quantities" of thiamine, riboflavine and nicotinic acid likely to be consumed by the prisoners in Ukonga Prison, Tanganyika, after September 1961

Diet

(A) Full diet before September, 1961, containing $96 \%$ extraction maize

$(B)$ Full diet after September, 1961, containing $60 \%$ extraction maize

(C) Diet after September, 1961, containing $60 \%$ extraction maize, when groundnuts were not eaten

$(D)$ Diet as in $(C)$ allowing for $20 \%$ loss of nutrients in wastage or cooking

$\begin{array}{cccc}\begin{array}{c}\text { Thiamine } \\ \text { (mg) }\end{array} & \begin{array}{c}\text { Riboflavine } \\ \text { (mg) }\end{array} & \begin{array}{c}\text { Nicotinic } \\ \text { acid } \\ (\mathrm{mg})\end{array} & \begin{array}{c}\text { Calories } \\ \text { (kcal) }\end{array} \\ 3.12 & 1.47 & 23.58 & 3329 \\ 1.56 & 0.85 & 17.96 & 3279 \\ 1.05 & 0.77 & 8.32 & 2951 \\ 0.84 & 0.62 & 6.66 & 2361\end{array}$

- Calculated from tables of Platt (1962).

However, questioning of the patients revealed that six never ate the groundnuts supplied; the other two ate them only occasionally, and did not like them. For prisoners not eating groundnuts, the assessed level of intake of thiamine was reduced to $\mathrm{x} \cdot 05 \mathrm{mg}$, of riboflavine to $0.77 \mathrm{mg}$ and of nicotinic acid to $8.32 \mathrm{mg}$ (see Table $2(C)$ ).

All prisoners throughout Tanganyika receive one $50 \mathrm{mg}$ tablet of nicotinic acid per week, which raises the intake by approximately $7 \mathrm{mg} /$ day.

The figures given in $(A),(B)$ and $(C)$ of Table 2 are maximum figures, not taking account of food that is pilfered, wasted, or discarded, or of loss of nutrients in storage, cooking, or through incomplete absorption. It is likely that once vitamin deficiencies occurred in these prisoners their appetites became impaired, and a vicious circle was set up. Conversely, poor appetite from some other cause may have initiated the train of events. A loss of $20 \%$, giving an intake shown in $(D)$, Table 2, seems to be a fair assumption. 


\section{Aetiology}

There is strong evidence to suggest that this outbreak of disease was due to a prolonged intake of a diet deficient in B vitamins. The food intake of these prisoners during periods varying from 8 to 48 months before the onset of the disease is known with unusual accuracy. The change from a maize meal of high to one of low extraction was probably the precipitating factor. Which particular B vitamin is concerned is difficult to say, and it is perhaps more likely that this syndrome results from a multiple deficiency. The possible role played by pantothenic acid has not been investigated. Groundnuts are a good source of this vitamin, and the amount in cereal grains is reduced by refining. However, the requirements of man have not been conclusively determined. Deficiency of pantothenic acid produces convulsions and coma in dogs (Schaefer, McKibbin \& Elvehjem, 1942), ataxia in monkeys (McCall, Waisman, Elvehjem \& Jones, 1946), and degenerative changes in the peripheral nerves, the posterior roots and the posterior columns of the cord in pigs (Swank \& Adams, I948; Follis \& Wintrobe, 1945). Deficiency is rare in man in ordinary life, since the vitamin is widely distributed in foods.

Protein deficiency has been thought to contribute to certain nutritional neuropathies. These patients were, however, receiving over $100 \mathrm{~g}$ protein daily, so it was unlikely to be a factor.

Typical signs of specific vitamin deficiencies were not seen. The patients were not thin or emaciated, their muscles were not wasted, there was no foot drop, and they lacked other features of dry beriberi. None showed oedema or other signs of wet beriberi. Only one had angular stomatitis, and none had other signs typical of riboflavine deficiency. None showed the skin lesions, the digestive symptoms, or the mental changes of pellagra. Most likely, deficiency of more than one vitamin in the diet was the cause of the syndrome.

The nervous system is a finely adjusted mechanism, utilizing a wide range of complex enzyme systems to control the use of energy supplied to it. The prosthetic group of these enzymes is frequently a vitamin, and it would not therefore be surprising to find several deficiencies involved in one neurological syndrome. Some as yet unidentified vitamin may, of course, possibly be involved.

\section{DISCUSSION}

The neuropathy described here had some similarities to the burning feet syndrome or nutritional melalgia which has been described among civilian populations subsisting on parboiled rice, and which assumed prominence as a major malady among European prisoners in the Far East during the Second World War. In many of these prisoners, mouth lesions and genital dermatitis occurred (Cruickshank, 1947), and in others pellagrous skin, amblyopia or oedema were observed (Smith, 1947). Weight loss was extremely common (Allen \& MacGregor, 1947). These signs were not features of the patients described in this paper.

The aetiology of the burning feet syndrome is still not clear. Gopalan (1946) found 
little or no improvement with thiamine, riboflavine, or nicotinic acid, but he reported dramatic improvement after the administration of calcium pantothenate. However, in a controlled trial in Ceylon, pantothenic acid produced no significant improvement (Bibile, Lionel, Dunuwille \& Perera, 1957).

Cases of nutritional neuropathy have from time to time been described in Africa. However, in all previously recorded cases, the patients have entered hospital from their home environment, and it was impossible to estimate their food intake. Questioning might reveal the different foods consumed, but not their quantities. For the first time, this syndrome has been observed in a group of persons whose diet during the months before its onset was known with some degree of certainty. It occurred some months after a change in the diet which markedly affected the intake of $\mathbf{B}$ vitamins, without altering the calorie intake or significantly affecting the intake of minerals, other vitamins, protein, and fat. Investigation revealed no toxic or infective cause for the outbreak.

People in Tanganyika, especially the urban dwellers, are rapidly changing over from unrefined to highly refined maize as their staple food. An increasing incidence of this condition can therefore be expected, especially among members of the community who neither consume a mixed diet nor partake of the many available beverages, both alcoholic and non-alcoholic, made from germinating cereals.

Legislation has recently been drafted in Tanganyika to ensure an adequate level of thiamine, riboflavine and nicotinic acid in all cereal flours. When operative, this legislation will forbid the sale of any cereal flour with less than $0.3 \mathrm{mg}$ thiamine, $0.1 \mathrm{mg}$ riboflavine and $3.0 \mathrm{mg}$ nicotinic acid per $100 \mathrm{~g}$, and will, it is assumed, prevent outbreaks of diseases such as the one described here. Such legislation is therefore an important public health measure.

\section{SUMMARY}

1. An ataxic neurological syndrome in eight prisoners in Tanganyika is described.

2. Their diet for the 9 months before the onset of the illness, known with unusual accuracy, since they had been confined to prison, has been investigated and assessed from food tables.

3. The disease is believed to be due to a multiple deficiency of $B$ vitamins, the immediate cause of the outbreak being a change from unrefined to highly refined maize meal.

4. Legislation to enforce an adequate level of certain B vitamins in cereal flours should prevent this syndrome.

The sufferers from the ataxic neurological syndrome were the patients of Dr David Haddock, Consultant Physician, Dar es Salaam. I thank him and also the officers and staff of Ukonga Prison, who gave their full co-operation during the investigation. I am also indebted to Dr W. J. Maelor Evans, Chief Medical Officer, Tanganyika, for granting me permission to publish this paper. 


\section{REFERENCES}

Allen, G. V. \& MacGregor, R. G. S. (1947). Proc. Nutr. Soc. 5, 107.

Bibile, S. W., Lionel, N. D. W., Dunuwille, R. \& Perera, G. (1957). Brit. F. Nutr. I1, 434.

Cruickshank, E. K. (1947). Proc. Nutr. Soc. 5, 121.

Follis, R. H. Jr. \& Wintrobe, M. M. (1945). F. exp. Med. 81, 539.

Gopalan, C. (1946). Indian med. Gaz. 81, 22.

Haddock, D. R. W., Ebrahim, G. J. \& Kapur, B. B. (1962). Brit. med. F. ii, 1442.

McCall, K. B., Waisman, H. A., Elvehjem, C. A. \& Jones, E. S. (1946). F. Nutr. 31, 685.

Money, G. L. (1958). W. Afr. med. F. 7, 58.

Money, G. L. (1959). W. Afr. med. F. 8, 3 .

Platt, B. S. (1962). Spec. Rep. Ser. med. Res. Coun., Lond., no. 302.

Schaefer, A. E., McKibbin, J. M. \& Elvehjem, C. A. (1942). J. biol. Chem. 143, 321.

Smith, D. A. (1947). Proc. Nutr. Soc. 5, 95.

Swank, R. L. \& Adams, R. D. (1948). $\mathscr{~ F . ~ N e u r o p a t h . ~ 7 , ~} 274$. 